Tropical Agricultural Pesearch \& Extension 21 (3 \& 4): 2018

\title{
ACADEMIC PERFORMANCE OF UNDERGRADUATES OF THREE NEW BSC DEGREE PROGRAMS AS AFFECTED BY GENDER AND, A/L STUDY STREAM AND SUBJECT PERFORMANCE
}

\author{
Mudalige $\mathrm{SKK}^{1}$, Atapattu NSBM${ }^{2 *}$, Dharmadasa $\mathrm{NP}^{1}$ \\ ${ }^{1}$ Dean's Office, ${ }^{2}$ Department of Animal Science, Faculty of Agriculture, University of Ruhuna, \\ Mapalana, Kamburupitiya, Sri Lanka
}

\begin{abstract}
Objective of this study was to determine the academic performance of undergraduates of three new BSc degree programs as affected by gender and, $\mathrm{A} / \mathrm{L}$ stream and subject performance. Semester grade point averages (SGPA) over eight semesters and overall grade point averages (OGPA) of 239 undergraduates who followed BSc in Green Technology (GT), Agricultural Recourse Management and Technology (AT) and Agribusiness Management (AB) were analyzed. Significantly higher percentage of GT (91\%), AB (73\%) and AT (70 \%) students had followed Biological Science as their Advanced Level (A/L) stream. The contributions of physics, Chemistry and Biology to the final $\mathrm{A} / \mathrm{L}$ performance of the students who followed biology stream were 30,33 and $37 \%$, respectively. Contrary, among those who had followed Agriculture, the contribution of Chemistry (22\%) was significantly lower than that of Biology stream students (33\%). Subject Agriculture contributed $44 \%$ to the final A/L performance of the students who had followed Agriculture in $\mathrm{A} / \mathrm{L}$. Nine percent of the students had dropped the undergraduate programs after taking examinations in one or even three semesters while another $20 \%$ have failed to complete the programme within the four-year period. Repeaters were significantly higher among male students and those who had followed Agriculture in A/L. Among GT, AB and AT students, the percentage of graduates with a class was 78, 65 and $56 \%$, respectively. Among students having first or second Class Upper Division grades, 87 and $65 \%$, respectively were females. First semester GPA values were significantly different among the three degree programs. Clear increases in SGPA values were seen from $6^{\text {th }}$ semester in GT program and from $4^{\text {th }}$ semester in AB and AT programs, eventually leading to have statistically similar SGPA values in the $8^{\text {th }}$ semester. In all three programmes, there was a significant linear relationship $\left(r^{2}=0.90, p=0.000\right)$ between OGPA values and the $4^{\text {th }}$ semester SGPA values. The study concludes that students who follow Agriculture stream in $\mathrm{A} / \mathrm{L}$ get an advantage over those who follow biology stream, in university admission for the BSc degree programs studied. Academic performance of females and, those who followed biology stream was found to better than males and those who followed Agriculture in the Advanced Level, respectively. Lower degree completion rate within the stipulated time, high drop-out rate, gender inequality in academic performance, and deficiencies of the curriculum of $\mathrm{A} / \mathrm{L}$ agriculture stream are identified as the critical issues to be addressed.
\end{abstract}

Keywords: Academic performance, Advanced Level, gender, OGPA, SGPA, undergraduates

\section{INTRODUCTION}

Having revised and restructured several occasions, the original curriculum of the BSc (Agriculture) Degree program which was introduced in 1978, the Faculty of Agriculture, University of Ruhuna has launched a new Degree program; BSc (Agricultural Resource

\footnotetext{
*Corresponding author: mahindaatapattu@gmail.com
}

Management and Technology) along with two more new degree programs, in 2013. The first cohort of students of each of the above programs was enrolled in 2012 and graduated in 2016.

Regular adjustments in curriculum and assessment of the programmes are among the vital 
components of a teaching-learning environment of a progressive higher educational institute. Apart from stakeholder opinion, analysis of students' academic performance can also serve as a valuable tool in making adjustments in curriculum and assessments. In general, good exam results encourage students (Artino et al. 2010; Abdulghani et al. 2012) while increasing their opportunities for employments and higher studies and after- graduation earnings (Smith et al., 2000; Smith and Naylor 2001). Meanwhile, undergraduate level academic performance are influenced by a range of factors including university entrance level qualification, gender, socio-economic background of the students, students personal commitments, learning style, etc. (Smith and Naylor, 2001). In a comprehensive study in the UK, across many disciplines, Smith and Naylor (2001) showed that undergraduate performance is positively correlated with $\mathrm{A} / \mathrm{L}$ results. McKenzie and Schweitzer (2001) showed that performance at university entry accounted for $39 \%$ of the variance in undergraduate performance.

In Sri Lanka, admission of students to state universities is based on $\mathrm{A} / \mathrm{L}$ performance as determined by $\mathrm{Z}$ score. Students who followed either Biology or Agriculture stream can apply for all the Agriculture and related degree programs including AT, GT and AB. Since subject combination of two streams differs markedly, knowledge at the time of university entrance can also be expected to be vary depending on the $\mathrm{A} / \mathrm{L}$ stream followed. Moreover, due to the complex selection process, the variation among the students as indicated by $\mathrm{Z}$ score could also be huge. The objective of the present study was to analyze the undergraduate academic performance of three new degree programs as affected by $\mathrm{A} / \mathrm{L}$ stream of study, subject performance and, gender. Since one cohort of students completed the whole program of the respective degrees, it is expected that analysis would assist to fine-tune the curriculum and assessment procedures of these degree programs.

\section{MATERIALS AND METHODS}

The study was conducted at the Faculty of Agriculture, University of Ruhuna, Sri Lanka. Drop-out rate, semester-wise academic performance and overall grade point average of undergraduates who followed GT $(n=48), A B$ $(n=49)$ and AT $(n=142)$, along with respondents' gender and GCE (A/L) subject-wise gradings were subjected to analysis. Sample characteristics are given in Table 3. Many students failed to recall their $\mathrm{Z}$ score. Furthermore, students' subject-wise marks at the A/L examination were not accessible. Therefore, subjectwise academic performance in $\mathrm{A} / \mathrm{L}$ was considered. A, B, C and S grade were given score of 4, 3, 2 and 1, respectively. Total academic performance was calculated as the sum of scores for all three subjects. For example, a total of 11 points was assigned to a student who had obtained A grades for two subjects and a B grade for the other subject. The contributions of the subject with A, A and B to the total performance were considered $36.36 \quad(=4 / 11$ X 100), 36.36 and $27.28 \%$, respectively. GT and AB programs were completely new degree programs while AT program can best be regarded as a restructured, revised, renamed version of the previous BSc (Agriculture) degree program. A detailed description of the three programs is available on www.ruh.agri.ac.lk. A summary of the course structure and other basic features are given in Table 1 . Up to $4^{\text {th }}$ semester, many courses were common for $\mathrm{AB}$ and AT programs. In the $6^{\text {th }}$ semester, AT students mainly engage in farm practice course. Farm practice course is offered as an optional course for $A B$ students. At the end of the $6^{\text {th }}$ semester, students select their specialization areas. Departmental level specialization programs are commenced at the $7^{\text {th }}$ semester followed by a research and dissertation submission in the $8^{\text {th }}$ semester. During the $7^{\text {th }}$ semester, students follow courses offered by his or her specialization areas along with some common courses. 
Semester Grade Point Average (SGPA) is calculated using the following formula and students will have grades based on their SGPA (Table 2).

\section{SGPA $=\mathrm{Ci}$ Gi $/ \mathrm{Ci}$}

Where,

$\mathbf{C i}$ is the number of credits for $\mathrm{i}^{\text {th }}$ course

Gi is the grade point obtained for the $i^{\text {th }}$ course

The Overall Grade Point Average (OGPA) will be calculated at the end of each semester using the formula;

\section{OGPA $=$ Cij Gi $/ \mathbf{C i j}$}

Where,

$\mathbf{C i}$ is the number of credits for the $\mathrm{i}^{\text {th }}$ course in the $\mathrm{j}^{\text {th }}$ semester.

Gi is the grade point obtained for the $i^{\text {th }}$ course.

Data were statistically analyzed using Minitab $\mathrm{V}$ 14. One sample and two sample $t$ tests, one proportions and two proportions tests were conducted where applicable. SPGA and GPA among three degree programs were analyzed using ANOVA. Means were compared using

Table 1: A summary of the course structure, teaching, and evaluation procedures of the three degree programs studied

\begin{tabular}{|c|c|c|c|}
\hline \multirow{2}{*}{ Item } & \multicolumn{3}{|c|}{ Degree program } \\
\hline & GT & $\mathbf{A B}$ & AT \\
\hline $\begin{array}{l}\text { Minimum no of course } \\
\text { credits per semester }\end{array}$ & 22 & 22 & 22 \\
\hline $\begin{array}{l}\text { Total number of compul- } \\
\text { sory course credits }\end{array}$ & 104 & 95 & 114 \\
\hline $\begin{array}{l}\text { Minimum requirement of } \\
\text { elective course credits }\end{array}$ & 8 & 18 & 6 \\
\hline Specialization semesters & $7^{\text {th }}$ and $8^{\text {th }}$ semester & $7^{\text {th }}$ and $8^{\text {th }}$ semester & $7^{\text {th }}$ and $8^{\text {th }}$ semester \\
\hline Common courses & $\begin{array}{l}\text { ICT, Statistics, Career } \\
\text { guidance }\end{array}$ & $\begin{array}{l}\text { ICT, Statistics, Career } \\
\text { guidance }\end{array}$ & $\begin{array}{l}\text { ICT, Statistics, Career guid- } \\
\text { ance }\end{array}$ \\
\hline $\begin{array}{l}\text { Industrial training credit } \\
\text { number }\end{array}$ & 6 & 2 & 2 \\
\hline Research credits & 6 & 6 & 6 \\
\hline Minimum total credits & 124 & 121 & 128 \\
\hline $\begin{array}{l}\text { Departments involve in } \\
\text { teaching }\end{array}$ & $\begin{array}{l}\text { Mainly Agric Engineering } \\
\text { and some other Depart- } \\
\text { ments for common courses }\end{array}$ & $\begin{array}{l}\text { Mainly Agric Economics } \\
\text { and some other Depart- } \\
\text { ments for Common } \\
\text { courses }\end{array}$ & All the departments \\
\hline $\begin{array}{l}\text { Specialization selection } \\
\text { of students }\end{array}$ & Mainly Agric Engineering & Mainly Agric Economics & All departments \\
\hline Research involvement & $\begin{array}{l}\text { Mainly to Agric Engineer- } \\
\text { ing }\end{array}$ & $\begin{array}{l}\text { Mainly to Agric Econom- } \\
\text { ics }\end{array}$ & All departments \\
\hline $\begin{array}{l}\text { Availability of Optional } \\
\text { Courses }\end{array}$ & From $3^{\text {rd }}$ semester onward & $\begin{array}{l}\text { From } 5^{\text {th }} \text { Semester on- } \\
\text { ward }\end{array}$ & From $5^{\text {th }}$ Semester onward \\
\hline Farm practice course & No & Optional & Compulsory; 17 weeks \\
\hline Assessments & $\begin{array}{l}\text { Continuous assessment }+ \\
\text { end semester assessment }\end{array}$ & $\begin{array}{l}\text { Continuous assessment }+ \\
\text { end semester assessment }\end{array}$ & $\begin{array}{l}\text { Continuous assessment }+ \text { end } \\
\text { semester assessment }\end{array}$ \\
\hline $\begin{array}{l}\text { End semester examina- } \\
\text { tions }\end{array}$ & $\begin{array}{l}\text { Written tests (MCQ, es- } \\
\text { says), practical/spot tests, } \\
\text { Viva }\end{array}$ & $\begin{array}{l}\text { Written tests (MCQ, es- } \\
\text { says), practical/spot tests, } \\
\text { Viva }\end{array}$ & $\begin{array}{l}\text { Written tests (MCQ, essays), } \\
\text { practical/spot tests, } \\
\text { Viva }\end{array}$ \\
\hline $\begin{array}{l}\text { Contribution from con- } \\
\text { tinuous evaluation com- } \\
\text { ponent }\end{array}$ & Vary from $20-50$ & Vary from $20-50$ & Vary from $20-50$ \\
\hline
\end{tabular}


Turkey test. Categorical variables were analyzed using chi-square test. Linear, quadratic, and cubic relationships between SGPAs of each semester and OGPA were determined. The best relationship was chosen based on the significance level and the $r^{2}$ value.

\section{RESULTS AND DISCUSSION}

Table 3 presents the academic performance of undergraduates of three degree programs as affected by gender, A/L stream, and subject performance. There was a good gender balance among the students of GT and AB programs while in AT program, the percentage of female students was significantly higher than males (Table 3). A similar female dominancy in Agricultural undergraduate degree programs has been reported in USA as well (Archibeque-Engle, 2016). Gunawardena (2015) showed that the percentage of female undergraduates in Sri Lankan universities increased during last three decades reaching up to $60 \%$ in 2013. In all three programs, the percentages of students who followed Biological science stream were significantly higher than those followed Agriculture stream in their advanced level. A study in Rajarata University (Karalliyadda, 2017) also reported that $74 \%$ of the BSc Agriculture undergraduates had followed Biology stream in A/Ls. A majority $(62 \%)$ of the students who followed Agriculture stream had been selected to AT programs while $30 \%$ and $8 \%$ of them had been enrolled to AB and GT degree programs, respectively (Chi square $p<0.01$ ). For many of the Districts, minimum $\mathrm{Z}$ scores of GT and $\mathrm{AB}$ programs were higher than that for $\mathrm{AT}$ program (www.ugc.lk). However, due to the selection procedure, $\mathrm{Z}$ score varied widely even within the students of a given degree program. The minimum cut-off $Z$ scores in the first round of selection for $\mathrm{GT}, \mathrm{AB}$, and AT programs varied with a side range; from 1.0759 to -0.1595 for AT program, from 1.1459 to -0.1748 for $\mathrm{AB}$ program, and from 1.1893 to -0.5175 for GT program. However, it should be noted that some of the students having high $\mathrm{Z}$ scores had left the course opting to follow other courses according to their selection option in the university entrance and new students with lower $Z$ scores have been admitted in subsequent rounds of selection. Therefore, the Z-scores of the students who followed the courses could be much lower than what is represented by the initial minimum cut-off $\mathrm{Z}$ scores. Meanwhile, GCE (A/ L) performance as determined by the performance for each subject showed no significant difference among the students selected to each program. Complexity in the university selection process that involves selection of students from different $\mathrm{A} / \mathrm{L}$ subject streams, and district quota system could be the reason for above discrepancies. Following sections

Table 2: Scheme of SGPA and GPA calculation

\begin{tabular}{ccccc}
\hline \multicolumn{2}{c}{ Grading for SGPA calculation } & \multicolumn{2}{c}{ Designation of classes according to OGPA } \\
\hline Marks (\%) (Out of 100) & Grade & Grade Points & SGPA & Grade \\
\hline$>=85$ & A + & 4.0 & OGPA $>=3.70$ & First Class \\
$80-84$ & A & 4.0 & $3.30<=$ OGPA $<3.70$ & Second Class Upper Division \\
$75-79$ & A- & 3.7 & $2.70<=$ OGPA $<3.30$ & Second Class Lower Division \\
$70-74$ & B + & 3.3 & $2.00<=$ OGPA $<2.70$ & Pass \\
$65-69$ & B & 3.0 & OGPA $<2.00$ & \\
$60-64$ & B- & 2.7 & & \\
$55-59$ & C + & 2.3 & & \\
$50-54$ & C & 2.0 & & \\
$45-49$ & C- & 1.7 & & \\
$40-44$ & D & 1.3 & & \\
$40>$ & F & 0 & & \\
\end{tabular}


Table 3: Academic performance of undergraduates of three degree programs as affected by gender, A/L stream, and subject performance

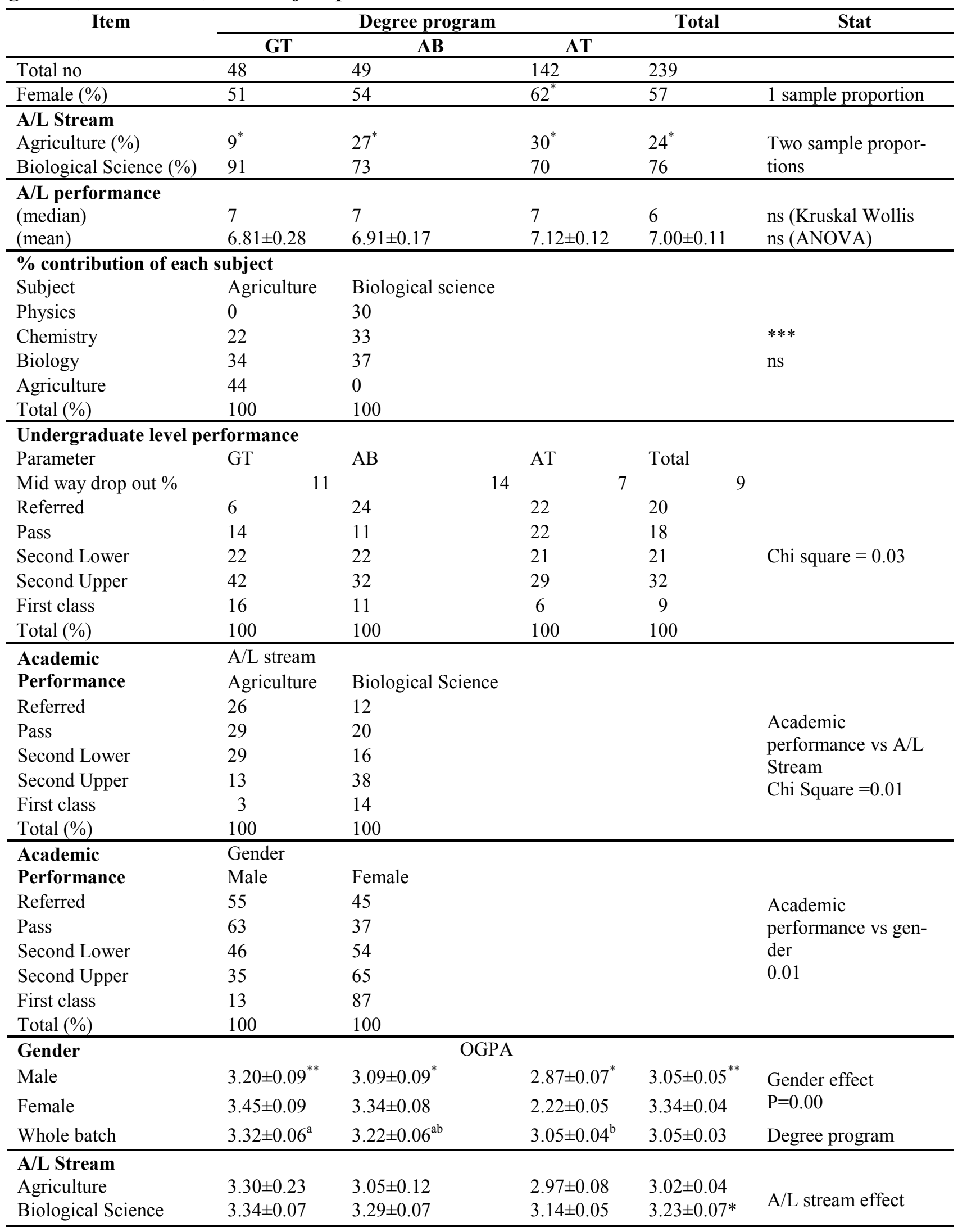


discuses a number of negative implications arisen from the above situation.

Main difference of the subject combinations of $\mathrm{A} / \mathrm{L}$ Agriculture and Biology stream is the Agriculture students' omission of Physics in place of Agriculture. Differences between above subject combinations and the contribution of each subject to the final $\mathrm{A} / \mathrm{L}$ performance on which university selections are determined, highlighted a number of important issues. The contributions of Physics, Chemistry and Biology to the final $\mathrm{A} / \mathrm{L}$ performance of the students who followed Biology stream being 30, 33 and $37 \%$ were found to be well balance. Contrary, among those who had followed Agriculture, the contribution of Chemistry, Biology and Agriculture were 22, 34 and $44 \%$, respectively. Apart from no contribution from Physics, the contribution of Chemistry was also significantly lower among Agriculture stream students (22\%) than Biology students (32\%). Having contributed $44 \%$ to the final $\mathrm{A} / \mathrm{L}$ performance, the subject Agriculture seems to be disproportionately benefited to the students who had followed Agriculture in $\mathrm{A} / \mathrm{L}$ for the university entrance. Consequently, some of the better students who have done Biology stream which includes Physics as a subject might have missed the opportunity of university entrance due to easiness of the Agriculture paper and/or the subject combination of the Agriculture stream; i.e. opting out of Physics.

McKenzie and Schweitzer (2001) showed that university entry performance accounted for 39 $\%$ of the variance in university GPA. Meanwhile, studies done in Faculties of Agriculture in Rajarata University of Sri Lanka (Weerahewa et al., 2013) and Ruhuna University (Mudalige et al., 2008) found that the performance at the Advanced Level examination, as measured by the $\mathrm{Z}$ score, had no influence on undergraduate academic performance. However, results of the present study revealed that, though the students had studied subject Agriculture for two years during their A/Ls, academic performance of the students who followed Agriculture stream was lower than that of Biology stream students (Table 3 and Fig 1). This suggests that compared to Agriculture, A/L Biology steam better prepares students to effectively follow the three programmes considered. Hazari et al. (2007) showed a strong relationship between the level of high school Physics knowledge and undergraduate performance. Omission of Physics and lower performance in Chemistry may place the students who follow Agriculture stream at a disadvantageous position in following the GT, AB and AT degree programs which require a sound understanding in Physics and Chemistry. Poor undergraduate-level performance of the students who got selected through $\mathrm{A} / \mathrm{L}$ Agriculture stream suggest the need of revisions for A/L Agriculture curriculum.

\section{Undergraduate level performance}

As high as 14 and $11 \%$ of the AB and GT students have dropped the respective programs after sitting examinations in one or even three semesters. Although, such mid-way drop outs were low (7\%) among AT students, the overall drop-out rate was around $9 \%$. Contrary to Sonnert and Fox (2012) who pointed out that students with high SGPA at initial semester are less likely to drop-out the courses, among those who dropped-out, there were students having both good as well as very low SGPA values. Given that enrolment for the Agricultural and Science-based courses are reported to be substantially lower than their capacities, results of this study emphasizes the need of interventions to retain those who have enrolled. Reasons for drop outs are complex and diverse (Willging and Johnson, 2009). Apart from personal and academic counseling mechanisms, careful curricula designing and assessment methods both in university and in GCE (A/L) examinations are important.

In a comprehensive study considering a wide range of degree programs in the UK, Smith and Naylor (2001) showed that the percent- 
ages of first classes, second uppers, second lowers, third classes and failures were 8, 40, 27,4 and $13 \%$, respectively. In line with above reports among GT, AB and AT students, the percentage of graduates with a class was 78,65 and $56 \%$, respectively. An analysis done by Mudalige et al. (2010) on the academic performance of the BSc (Agriculture) program (a predecessor of the present AT program) showed even higher percentage (71 $\%$ ) of graduates with a class. The percentage of first classless among GT students was two times higher than the level reported by Mith and Naylor (2001).

Twenty percent of the undergraduates have failed to complete the courses within four year period. Since no repeat examinations are conducted, those repeat students have to wait at least another year to graduate. Such repeating students are high among $\mathrm{AB}(24 \%)$ and AT students $(22 \%)$ than GT $(6 \%)$ cohorts. Furthermore, repeaters were significantly higher among those who followed Agriculture in $\mathrm{A} / \mathrm{L}(26 \%)$ than among those who followed Biology stream (12\%). This observation further supports the argument that there exists a mismatch between knowledge and skills that A/L Agriculture syllabus imparts and what University expects at the enrollment.

Smith and Naylor (2001) showed that academic performance of female Agriculture undergraduate students was significantly lower than that of male students. Contrary to them, across all three degree programs and eight semesters, female outperformed male students. Among students who secured either first or second uppers 87 and $65 \%$, respectively were females. Among repeaters also, majority were male students. Since many competitive employments and postgraduate opportunities require second upper or first classes, poor academic performance of male graduates may have numerous implications in their future careers and thus needs to be addressed.
In line with the situation in Agricultural Technology and Management degree programs, offered by the Faculty of Agriculture, University of Peradeniya (Weerahewa et al., 2012), among students who secured either first or second uppers 87 and $65 \%$, respectively were females. Among repeaters also, many were males. Fox (2012) also showed that in a range of degree programs, female undergraduates achieved higher GPA values than male students. SGPA values of all three degree programs were numerically higher among the students who followed Biology stream than those followed Agriculture. When averaged across all three degree programs, those who followed Biology have achieved higher OGPA value compared to those who did Agriculture.

SGPA values of the students in all eight semesters are shown in Figure 1. First semester SGPA values of all three programs were significantly higher than that Rajarata University Undergraduates (2.2117) reported by Karaliyadda (2017). Suggesting a marked increase in undergraduate performance, the first semester SGPA values reported in this study for all three degree programs were significantly higher than that of the BSc Agriculture degree program (2.4834) offered by the same Faculty, back in 2008 (Mudalige et al., 2012). SGPA values of the students following three degree programs were significantly different in the first semesters. Meanwhile, SGPA values in $6^{\text {th }}$ and $8^{\text {th }}$ semesters were not statistically different among three degree programs. It is interesting to note that irrespective of the marked differences in academic performance in other semesters, performance in $6^{\text {th }}$ and $8^{\text {th }}$ semesters, during which they mainly engage in field/on farm trainings and research projects, respectively were similar.

GT students' SGPA values over the eight semesters could best be described as a significant quadratic relationship. Among GT students, SGPA reduced during first three semesters, then increased in the fourth semester and maintained at a more or less similar level dur- 
ing $5^{\text {th }}$ and $6^{\text {th }}$ semesters. During $7^{\text {th }}$ and eighth semester, SGPA values were increased again. Despite a peculiar increase in the $3^{\text {rd }}$ semester, AB students showed significant linear increase in their SGPA values as they progress the semesters. AT students' SGPA value showed a significant quadratic relationship with the progression of academic program. Both among AT and AB students, there was a clear increase in SGPA values from $4^{\text {th }}$ semester onward eventually resulting in a similar SGPA values among the students of all three programs studied.

Interestingly, irrespective of the degree program, students performed extremely better in their research component; i.e. $8^{\text {th }}$ semester. Almost $50 \%$ of the students had achieved $\mathrm{A}^{+}$ or A while another $30 \%$ had achieved A- for their research project. $\mathrm{A}+$ or $\mathrm{A}$ grading for research project was higher among AT students $(44 \%)$ than among GT $(19 \%)$ or AB students $(29 \%)$. Significant linear relationships were observed between OGPA and the fourth semester SGPA for GT (OGPA = $0.8908+0.7248$ SGPA Sem 4$),$ AB $($ OGPA $=$ $1.066+0.6966$ SGPA Sem 4) and AT (OGPA $=0.8908+0.7248$ SGPA Sem 4) programs $\left(\mathrm{r}^{2}=0.90, \mathrm{p}=0.000\right)$.

\section{CONCLUSION}

Results of the present analysis conclude that the students who followed Agriculture stream in Advanced Level examination get an advantage in university entrance. However, poor performance in Chemistry and the omission of Physics in advanced level were found to have negative impact on their undergraduate level performance. High mid-way dropouts and low rate degree completion at the first attempt and the poor academic performance of the male undergraduates were the major issues to be addressed. In conclusion, results of the present study emphasize the need of close collaboration between universities and secondary education sector in curriculum designing, assessments, and university selection process.

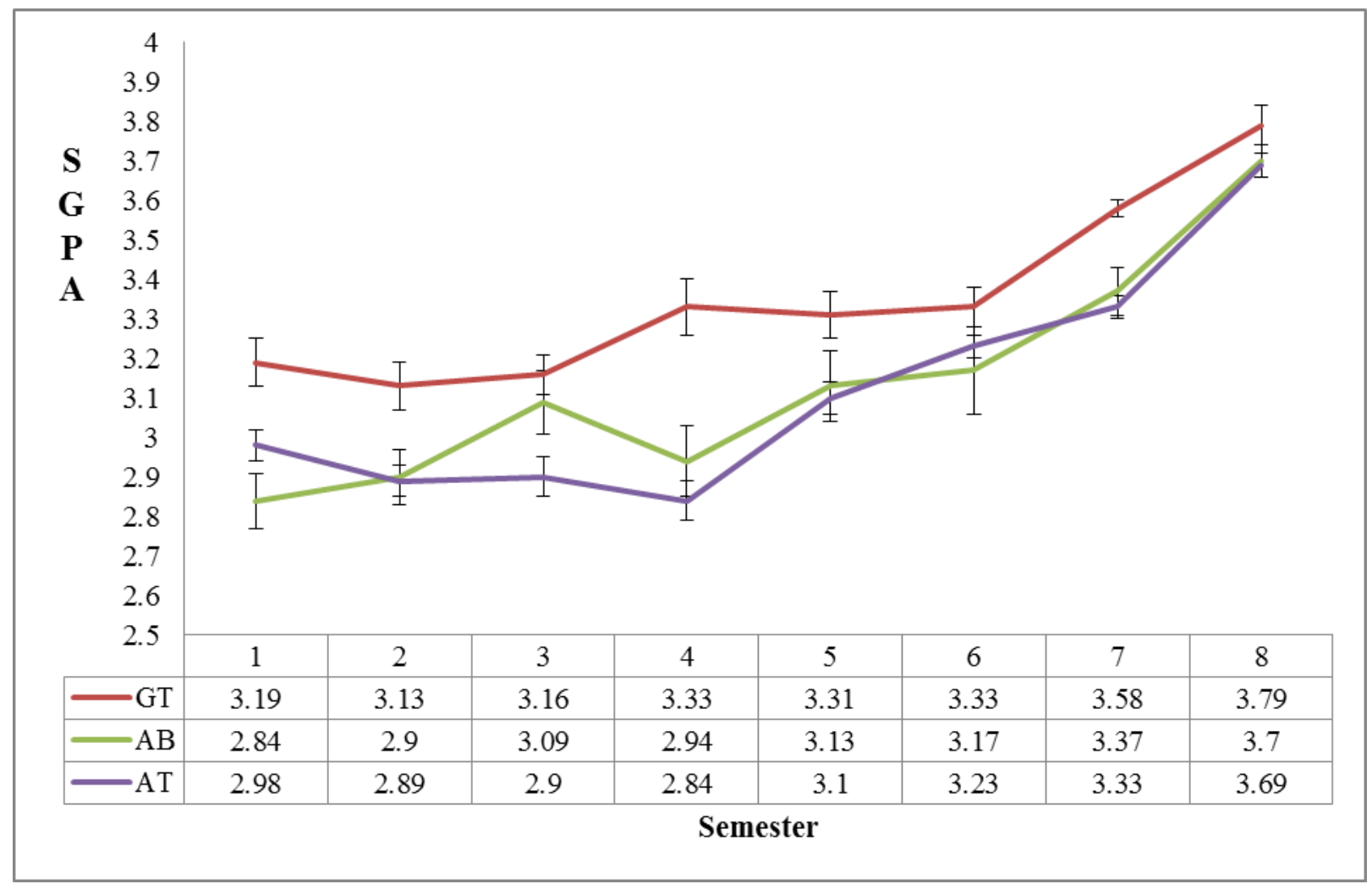

Figure 1: SGPA values of the students in all eight semesters 


\section{REFERENCES}

Abdulghani HM, Alrowais NA, Bin-Saad NS, AL-Subaie NM, Haji AM, AlHaqwi AI 2012 Sleep disorder among medical students: Relationship to their academic performance. Medical Teaching. 34:S37-S41.

Artino AR, La Rochelle JS, Durning SJ 2010 Second-year medical students' motivational beliefs, emotions, and achievement. Medical Education 44 (12):1203-1212

Archibeque-Engle, SL and Gloeckner G 2016 Comprehensive Study of Undergraduate Student Success at a Land Grant University College of Agricultural Sciences, 1990-2014. NACTA Journal, 60(4): 432.

Gunawardena NS 2015 Women in Sri Lanka: achievements and challenges. Journal of the College of Community Physicians of Sri Lanka, 20(1). Pp 4-23.

Hazari Z, Tai RH and Sadler PM 2007 Gender differences in introductory university physics performance: The influence of high school physics preparation and affective factors. Science Education, 91(6), pp.847-876.

Karalliyadda SMCB 2017 Learning Style and Academic Performance of First Year Agricultural Undergraduates: A Case in Rajarata University of Sri Lanka. Journal of Agricultural Sciences, 12(1): 34-42.

McKenzie K and Schweitzer R 2001 Who succeeds at university? Second-year medical students' motivational beliefs, emotions, and achievement. Medical Education. 44(12): 1203-1212.

Mudalige SKK, Atapattu NSBM \& Rangoda BDP 2010 Three decades: Two curricula: An analysis of the results of B.Sc. Agriculture graduates of Ruhuna University. Proceedings of the 7 th academic sessions of Ruhuna University: 60.

Mudalige SKK, Rangoda BDP and Atapattu NSBM 2008 From Z score to semester grade point average: An analysis. Proceedings of the 5th Academic Sessions of University of Ruhuna, Sri Lanka: 207.

Smith J, McKnight A and Naylor R 2000 Graduate employability: policy and performance in higher education in the UK. The Economic Journal, 110(464): 382-411.

Smith J and Naylor R 2001 Determinants of degree performance in UK universities: a statistical analysis of the 1993 student cohort. Oxford Bulletin of Economics and Statistics, 63(1), pp.29 -60 .

Sonnert G and Fox MF 2012 Women, men, and academic performance in science and engineering: The gender difference in undergraduate grade point averages. The Journal of Higher Education, 83(1): 73-101.

Weerahewa J, Bulathwela S, Silva P and Perera K 2013 An Analysis of Academic Performance of Undergraduates: Effects of Academic Vis-A-vis NonAcademic Factors. Proceedings of the Peradeniya University Research Sessions, Sri Lanka. http:// scholar.googleusercontent.com/ scholar?

$\mathrm{q}=$ cache:RJLtsVZzwasJ:scholar.googl e.com/

+ An + Analysis + of + Academic + Perfor mance + of + Undergraduates + Weerahe wa $+\& h l=$ en\&as $\mathrm{sdt}=0,5$

Willging PA and Johnson SD 2009 Factors that influence students' decision to dropout of online courses. Journal of Asynchronous Learning Networks, 13 (3): 115-127. 